\title{
Catalase Enhances Viability of Human Chondrocytes in Culture by Reducing Reactive Oxygen Species and Counteracting Tumor Necrosis Factor- $\alpha-$ Induced Apoptosis
}

\author{
Siming $\mathrm{Li}^{\mathrm{a}}$ Xiaohong Yang ${ }^{\mathrm{a}}$ Zhencheng Feng ${ }^{\mathrm{a}}$ Pengzhen Wang ${ }^{\mathrm{a}}$ Weicong Zhu ${ }^{\mathrm{a}}$ \\ Shuliang Cuia,b
}

aGuangzhou Institute of Traumatic Surgery, Guangzhou Red Cross Hospital, Jinan University School of Medicine, Guangzhou, China, 'D Department of Zoology, Faculty of Science, University of Melbourne, Melbourne, Australia

\section{Key Words}

Catalase (CAT) - Antioxidant - Tumor necrosis factor- $\alpha$ (TNF- $\alpha)$ - Death cascade - Antiapoptosis $\cdot$ Cell viability $\bullet$ C28/I2 chondrocytes

\begin{abstract}
Background/Aims: Both physiologic remodeling and pathologic regeneration of cartilage tissue rely upon chondrocyte functions and are benefited from factors that promote viability and inhibit apoptosis of the cell, and associated mechanisms. High level of reactive oxygen species (ROS) and proinflammatory cytokines activate apoptosis signaling and initiate cell death, which can be attenuated by antioxidants. This study examined the effect of catalase (CAT) on ROS and tumor necrosis factor- $\alpha$ (TNF- $\alpha$ )-induced apoptosis in human C28/I2 chondrocytes cultured in monolayer. Methods: Chondrocytes were treated with diluted CAT in the presence or absence of TNF- $\alpha$ and compared to untreated cells. Levels of hydrogen peroxide $\left(\mathrm{H}_{2} \mathrm{O}_{2}\right)$ and mitochondrial membrane potential $\left(\Delta \psi_{\mathrm{m}}\right)$ were measured using fluorescent labeling, cell apoptosis was assayed by flow cytometry using Annexin V/propidium iodide (PI) staining, gene expression was detected by quantitative real time polymerase chain reaction (qRT-PCR) and the proteins were investigated by Western blotting. Results: CAT effectively reduced the intracellular ROS caused by the monolayer culture system, enhanced the $\Delta \psi_{\mathrm{m}}$ depending on the presence of TNF- $\alpha$ and promoted morphological features at sub-cellular level. CAT also attenuated the TNF- $\alpha$-upregulated expression of factors/mediators of extrinsic cell death cascade and apoptotic caspases, ultimately resulted in promoted cellular viability. Conclusion: The anti-apoptotic effect of CAT on chondrocytes via scavenging ROS and suppressing TNF-
\end{abstract}


$\alpha$-induced cell apoptosis by TNF/TNF receptor (TNFR) mediated death signaling pathway and potentiate CAT as a complementary agent beneficial to cartilage remodeling and regeneration in vivo, and cell-based therapies of cartilage repair demanding viable cells expanded ex vivo.

(C) 2018 The Author(s)

Published by S. Karger AG, Basel

\section{Introduction}

The capacity of physiologic remodeling and pathologic repairing by regeneration in cartilage is low due to the low cellularity [1] and the only resident cells, the chondrocytes, are embedded and separated themselves in the extracellular matrix (ECM) [2, 3] and retained in senescent state $[4,5]$ until stimulated. The active chondrocytes sense the stimulatory signals in milieu through their interaction with ECM and respond by cellular secretions to govern the biological processes of physiologic remodeling and reparative regeneration in pathologic conditions, such as osteoarthritis (OA) [5, 6]. Promoting chondrocyte function by increasing its number in cartilage tissue seems out of the question, but can be achieved by maintaining their activity and reducing apoptosis, while both the large number and improved viability of chondrocytes in culture can be attained essentially useful for cell-based clinical treatments [7] and therapies, such as autologous chondrocyte implantation (ACI) [8-10]. Bio-factors that regulate chondrocyte activity, including retaining/promoting viability and reducing/ inhibiting apoptosis, would be important agents for achieving functional cells.

The loss of ECM in damaged cartilage initiates chondrocytic secretion of new proteins for repair causing unbalanced cartilage homeostasis [11] and elevated levels of inflammatory cytokines $[12,13]$, resulting in progressive tissue degeneration. The affected cells produce cytokines, such as interleukin-1 $\beta$ (IL-1 $\beta$ ), interleukin-6 (IL-6) and TNF- $\alpha[12,14]$, to promote catabolism [13]. The key inflammatory cytokine TNF- $\alpha$ and IL-1 $\beta$ coexist in the process of inflammation and pathogenesis in OA [12], the presence of TNF- $\alpha$ in cells, which is also stimulated by IL-1 $\beta$ [15], initiates inflammation and apoptosis by association with the TNF receptor (TNFR) on cell surface [16], leading to the formation of death inducing signaling complex (DISC). DISC recruits the TNF receptor-associated dead domain (TRADD), Fasassociated dead domain protein (FADD) to initiate the death signaling, which triggers the activation of apoptotic enzymes of caspase-8 (Cas-8) and caspase 3 (Cas-3) [17]. Significantly activated Cas-8 directly activates Cas- 3 to introduce apoptosis (the extrinsic route) rather than amplifying Cas-3 activation mediated by low levels of activated Cas- 8 via mitochondria (the intrinsic route) [18].

The excessive ROS damage the cell membrane, nucleic acids and mitochondria, and cause further inflammation and cell death through the TNFR-bridged ROS-TNF crosstalk [19]. The mitochondrion senses the redox imbalance [20], and vulnerable to damages that decrease the cell viability and generate apoptosis. The unstable superoxide stimulated by both endogenous and exogenous oxidative stresses [21] are readily converted by superoxide dismutase (SOD) to more stable form of hydrogen peroxide $\left(\mathrm{H}_{2} \mathrm{O}_{2}\right)$ and surrendered to further removal by antioxidant scavengers, such as CAT and glutathione peroxidase, which convert $\mathrm{H}_{2} \mathrm{O}_{2}$ to $\mathrm{H}_{2} \mathrm{O}[22,23]$. However, the highly permeable $\mathrm{H}_{2} \mathrm{O}_{2}$ can easily accumulate within both the mitochondrial matrix and cytosol and cause many diseases [24, 25]. High levels of intracellular $\mathrm{H}_{2} \mathrm{O}_{2}$ are ascribed to toxic DNA double-strand breaks in human alveolar epithelial cells (AECs) [26] and mitochondrial DNA damage in AECs of transgenic mice [27], both result in apoptosis and attenuated by CAT. The antioxidant defensing effect of CAT against lung fibrosis by reducing ROS and maintaining redox homeostasis is of evidence in a wide range of organisms [28]. It is of great interest to elucidate the effect of CAT on the intracellular level of ROS and apoptosis caused by TNF- $\alpha$ treatment in chondrocytes relevant to therapies for cartilage regeneration.

In the present study, the effects of CAT on its substrate of intracellular $\mathrm{H}_{2} \mathrm{O}_{2}$ and apoptosis was investigated using the immortalized human chondrocyte cell line $\mathrm{C} 28 / \mathrm{I} 2$ cells treated with TNF- $\alpha$ in monolayer culture. The cultured C28/I2 chondrocytes showed that CAT can effectively reduce the intracellular ROS caused by the monolayer culture system, counteract 
the negative effects of TNF- $\alpha$ on cultured chondrocytes to enhance the mitochondrial membrane potential $\left(\Delta \psi_{\mathrm{m}}\right)$ depending on the presence of TNF- $\alpha$, improve morphological features at sub-cellular level, attenuate upregulated factors/mediators of extrinsic cell death cascade and apoptotic caspases, and collectively reduced cell apoptosis. These results affirm the anti-apoptotic effect of CAT in chondrocytes through scavenging ROS and suppressing TNF- $\alpha$-induced cell apoptosis mediated by death cascade, which potentiates CAT as a complementary therapeutic agent beneficial to approaches of cartilage remodeling and regeneration in vivo, and cartilage repairs by cell-based therapies requiring large number of viable cells expanded ex vivo.

\section{Materials and Methods}

\section{C28/I2 chondrocytes cultured in monolayer}

The immortalized chondrocyte cell line, C28/I2, a kind gift to Guangzhou Institute of Traumatic Surgery from Professor Jiake Xu of the University of Western Australia, originally obtained from cells isolated from cartilage and transduced with simian virus 40 containing T-antigen [29], was employed in this study. The frozen cells were revived by thawing in a $37^{\circ} \mathrm{C}$ water bath and then cultured in DMEM-F12 medium (113300032, Gibco/Life Technology, Grand Island, NY, USA) containing 10\% fetal bovine serum (FBS) (10099141, Gibco/Life Technology) and 1\% penicillin/streptomycin (15140-122, Gibco/Life Technology) at $37^{\circ} \mathrm{C}$ and $5 \% \mathrm{CO}_{2}$ till $80 \%$ confluence with the medium changed every second day in the Forma STERI-CYCLE $\mathrm{CO}_{2}$ Incubator (8000DH (3543), Thermo Scientific, Marietta, OH, USA). The cells were washed with $1 \mathrm{X}$ phosphate buffered saline (PBS) and treated with $0.02 \%$ EDTA before harvested by trypsin (GNM11900, Gibco/Life Technology) digestion at $37^{\circ} \mathrm{C}$ for 2-3 min. The cells were claimed by centrifugation and resuspended in DMEM-F12 medium supplemented with 10\% FBS and 1\% penicillin/streptomycin followed by incubation for cell propagation.

\section{Effects of CAT on cell viability of C28/I2 chondrocytes in culture}

$\mathrm{C} 28 / \mathrm{I} 2$ cells were cultured at $37^{\circ} \mathrm{C}$ and $5 \% \mathrm{CO}_{2}$ till $80 \%$ confluence and then allocated in a 96-well plate (167008, Nunclon ${ }^{T M}$ Delta Surface, Thermo Scientific, Suzhou, Jiangsu, China) at about 4 X $10^{3}$ cells/well in DMEM-F12 medium containing 10\% FBS and 1\% penicillin/streptomycin. The cells were treated with a series diluted catalase (S0082, Beyotime Biotechnology, Haimen, Jiangsu, China) with final concentrations of $2400,2000,1600,1200,800,400,200,100$ and $0 \mathrm{U} / \mathrm{ml}$ (equivalent volume of $1 \mathrm{X}$ PBS added as control) in culture. The treatments of cells were set in 3 replicates and cultured at $37^{\circ} \mathrm{C}$ with $5 \% \mathrm{CO}_{2}$ supplied in the incubator for $24 \mathrm{~h}$. Viability of those cells were analyzed by MTS using CellTiter $96^{\circledR}$ AQueous One Solution Cell Proliferation Assay as instructed by the manufacturer (Promega, Madison, WI, USA), in which the MTS tetrazolium compound is bioreduced by metabolically active cells into a colored soluble formazan product in culture medium and measurable by absorbance at $490 \mathrm{~nm}$ with a 96 -well plate reader. These chondrocytes in $100 \mu \mathrm{l}$ were mixed with $20 \mu \mathrm{l}$ of MTS reagent followed by a further culture for $4 \mathrm{~h}$ before analyzed using GloMax Multi+ Detection System (Promega) by measuring their absorbance values (A value). The differences of A values were examined using SSPS 22 for statistical significance.

\section{Establishment of TNF- $\alpha$-induced apoptotic model of C28/I2 chondrocytes}

C28/I2 chondrocytes were prepared as in "C28/I2 chondrocytes cultured in monolayer". When the cells grown $\geq 80 \%$ confluence, they were harvested by trypsinization in DMEM-F12 culture medium containing $0.02 \%$ EDTA and $1 \%$ antibiotics. About $6.5 \times 10^{5}$ cells were resuspended in $10 \mathrm{ml}$ of the culture medium and allocated in Nunc ${ }^{T M}$ EasYFlask $^{T M} 25-\mathrm{cm}^{2}$ Nunclon ${ }^{T M}$ Delta Surface (Thermo Scientific, Suzhou, Jiangsu, China) for each treatment by 3 replicates. The apoptosis of chondrocytes was induced by the Recombinant Human TNF- $\alpha$ (210-TA-005, R\&D System, Minneapolis, MN, USA) at 3 concentrations of 10,20 and $30 \mathrm{ng} / \mathrm{ml}(1 \mathrm{ng}=$ $76 \mathrm{IU}$ ) with equal volume of $1 \mathrm{X} \mathrm{PBS}$ applied as controls in culture at $37^{\circ} \mathrm{C}$ with $5 \% \mathrm{CO}_{2}$ for $24 \mathrm{~h}$.

Apoptosis was determined using the Annexin V-FITC Apoptosis Detection Kit (BMS500FI-300, Life Technologies, Carlsbad, CA, USA) according to the manufacturer's instruction. Chondrocytes cultured in monolayer were digested using trypsin and harvested in Corning ${ }^{\circledR} 15 \mathrm{ml}$ centrifuge tubes (CORNING 430790, NY, Mexico). Some 2 X $10^{5}$ cells were resuspended and washed in $2 \mathrm{ml}$ of $1 \mathrm{X}$ PBS, then suspended 


\section{Cellular Physiology Cell Physiol Biochem 2018;49:2427-2442 and BiOChemistry Published onIme: 28 September $2018 \begin{aligned} & \text { DO } 2018 \text { The Author(s). Published by S. Karger AG, Basel } \\ & \text { www.karger.com/cpb }\end{aligned}$}

Li et al.: Catalase Boosts Viability of Chondrocytes in Culture

in $200 \mu \mathrm{l}$ of $1 \mathrm{X}$ Binding Buffer. An aliquot of $195 \mu \mathrm{l}$ of suspended cells was mixed with $5.0 \mu \mathrm{l}$ Annexin V-FITC followed by an incubation at room temperature for $15 \mathrm{~min}$. The incubated cells were washed in $200 \mu \mathrm{l}$ of $1 \mathrm{X}$ Binding Buffer, resuspended in $190 \mu \mathrm{l}$ of $1 \mathrm{X}$ Binding Buffer and mixed with $10 \mu \mathrm{l}$ of propidium iodide $(20 \mu \mathrm{g} / \mathrm{ml})$ for Fluorescence-activated cell sorting analysis using BD FACSVerse ${ }^{\mathrm{TM}}$ System (BD Biosciences, San Jose, CA, USA). Fluorescein was stimulated at $488 \mathrm{~nm}$ and detected with a 515-560 $\mathrm{nm}$ bandpass filter. The analysis of flow cytometry (FCM) determined an appropriate concentration of TNF- $\alpha$ for establishing apoptotic cell model.

Detection of intracellular level of $\mathrm{H}_{2} \mathrm{O}_{2}$ in $\mathrm{C} 28 / \mathrm{I} 2$ chondrocytes.

C28/I2 chondrocytes prepared as in "C28/I2 chondrocytes cultured in monolayer" were allocated to wells of 96-well plate (Thermo Scientific) containing DMEM-F12 medium with 5\% FBS. Triplicates of 4 X $10^{3}$ cells/well in the final volume of $80 \mu \mathrm{l}$ was incubated at $37^{\circ} \mathrm{C}$ and $5 \% \mathrm{CO}_{2}$ for $18 \mathrm{~h}$ with 0 ( $1 \mathrm{X} \mathrm{PBS}$ added as control), 400, 800 and $1600 \mathrm{U} / \mathrm{ml}$ catalase in the presence or absence of $20 \mathrm{ng} / \mathrm{ml}$ of Recombinant Human TNF- $\alpha$ (R\&D System). The cells were mixed with $20 \mu \mathrm{l}$ of the $\mathrm{H}_{2} \mathrm{O}_{2}$ Substrate Solution from the ROS-Glo ${ }^{T M} \mathrm{H}_{2} \mathrm{O}_{2}$ Assay kit (G8820, Promega) and further incubated for $6 \mathrm{~h}$ in the same conditions. Cells in each well were mixed with $100 \mu \mathrm{l}$ of ROS-Glo ${ }^{T M}$ Detection Solution and kept in the dark at room temperature for $10 \mathrm{~min}$ before the luminescence was recorded using a GloMax ${ }^{\circledR}$ Multi Detection System (Promega).

Detection of mitochondrial membrane potential $\left(\Delta \psi_{m}\right)$

The $\Delta \Psi_{\mathrm{m}}$ maintains an electrochemical gradient across the mitochondrial membrane, which collapses in the process of cell death. The changes of $\Delta \psi_{\mathrm{m}}$ were detected using the Mitochondrial membrane potential assay kit with JC-1 (Beyotime) staining. The unique cationic dye, JC-1 (5, 5,6, 6-tetrachloro-1, 1,3, 3 tetraethylbenzimidazolylcarbocyanine iodide) is a membrane potential-sensitive probe that forms aggregates in the mitochondria with higher membrane potential showing fluorescent red at $590 \mathrm{~nm}$. With collapsed $\Delta \psi_{\mathrm{m}}$, monomers of the JC-1 remain in the cytosol of cells and emit a fluorescent green at $530 \mathrm{~nm}$. The intensity of the fluorescence is proportionally reflecting the $\Delta \psi_{\mathrm{m}}$ level. The ratio between $530 \mathrm{~nm}$ and $590 \mathrm{~nm}$ emission manifest the fettle of $\Delta \psi_{\mathrm{m}}$ [30]. The apoptotic C28/I2 cells were induced by TNF- $\alpha$ and treated with 400, 800 and $1600 \mathrm{U} / \mathrm{ml}$ as described in the early section. Some $1 \times 10^{6}$ treated chondrocytes were trypsinized and resuspended in $2 \mathrm{ml}$ of JC- 1 staining solution (100 $\mu \mathrm{l}$ of C2006-1 was mixed with 16 $\mathrm{ml}$ of $\mathrm{H}_{2} \mathrm{O}$ and $4 \mathrm{ml}$ of $\mathrm{C} 2006-3$ ), then incubated at $37^{\circ} \mathrm{C}$ with $5 \% \mathrm{CO}_{2}$ for $30 \mathrm{~min}$. Cells were harvested and washed with $2 \mathrm{ml}$ of $1 \mathrm{X} \mathrm{JC}-1$ solution twice before resuspended in $2 \mathrm{ml}$ of $1 \mathrm{X}$ PBS for fluorescent detection using a fluorospectrophotometer, the GloMax Multi Detection System (Promega) using their Fluorescence Optical Kits with excitation at $490 \mathrm{~nm}$ and emission at $510-570 \mathrm{~nm}$ for monomers (green), and excitation at $525 \mathrm{~nm}$ and emission at 580-640 $\mathrm{nm}$ for aggregates (red) as instructed by the manufacturer. The ratio of red to green fluorescence in JC-1 stained cells was used for defining changes of $\Delta \psi_{\mathrm{m}}$.

Examination of CAT effect on apoptotic features in TNF- $\alpha$-treated C28/I2 chondrocytes by acridine orange staining

C28/I2 chondrocytes were prepared as in "C28/I2 chondrocytes cultured in monolayer" and incubated at $37^{\circ} \mathrm{C}$ with $5 \% \mathrm{CO}_{2}$ in $25-\mathrm{cm}^{2}$ Nunc $^{T M}$ EasYFlask $^{T M}$ (Thermo Scientific). About $2 \mathrm{X} 10^{4}$ cells were applied onto a poly-L-Lysine (P4832, Sigma)-coated microscope cover glass ( $\varphi 18 \mathrm{~mm}$, CITOGLAS, Jiangsu, China) in wells of 12 -well plate containing DMEM-F12 with $10 \% \mathrm{FBS}$ and cultured in $5 \% \mathrm{CO}_{2}$ for $4 \mathrm{~h}$, then cultured cells were treated with $800 \mathrm{U} / \mathrm{ml}$ CAT (Beyotime) in the presence of TNF- $\alpha$ (20 ng/ml) for $24 \mathrm{~h}$. The cells were harvested and fixed with $4.0 \%$ paraformaldehyde on coverslip. The cells were washed and stained for 10 min using $0.01 \%$ acridine orange (A9231, Sigma) solution to specifically generate green emission for double-stranded nuclei acids (DNA) and orange-red for single stranded nuclei acids and aggregates in acidic microenvironment. Images of stained cells were viewed and captured using confocal laser scanning microscopy (CLSM, Zeiss LSM 510 META System) and compared to untreated cells. 


\section{Cellular Physiology Cell Physiol Biochem 2018;49:2427-2442

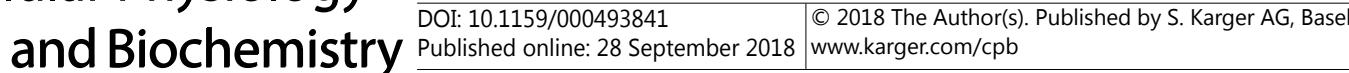

Li et al.: Catalase Boosts Viability of Chondrocytes in Culture

Table 1. Primers used for real-time polymerase chain reaction analysis

\begin{tabular}{lcccc}
\hline Gene name & Acc. No. & Sense primer (5'---3') & Antisense primer (5'---3') & Amplicon size \\
\hline TNFR-1 & NM_001346091.1 & CCATTGTTTGTGGGAAATCG & GGAGGTGAAGGTGGAACTGG & 152 \\
FADD & NM_003824.3 & CTGGCTCGTCAGCTCAAAGT & GTTGCGTTCTCCTTCTCTGTG & 128 \\
TRADD & XM_005256213.3 & TTTGAGTTGCATCCTAGCCC & GCACTTCAGATTTCGCAGC & 88 \\
Cas-8 & XM_011511969.1 & TTGACCACGACCTTTGAAGAG & AGCAGATGAAGCAGTCCATG & 130 \\
Cas-3 & XM_011532301.1 & TGGTTCATCCAGTCGCTTTG & AATTCTGTTGCCACCTTTCG & 101 \\
MMP-13 & NM_002427.3 & TTGAGCTGGACTCATTGTCG & CGCGAGATTTGTAGGATGGT & 126 \\
GAPDH & NM_001289746.1 & ACACCCACTCCTCCACCTTT & TTACTCCTTGGAGGCCATGT & 143 \\
\hline
\end{tabular}

Quantitative real time PCR ( $q$ RT-PCR) detection of gene expression of factors involved in death signaling pathway

The apoptotic C28/I2 cells were established as described in "C28/I2 chondrocytes cultured in monolayer". About $6 \times 10^{5}$ cells $/ \mathrm{ml}$ were cultured at $37^{\circ} \mathrm{C}$ with $5 \% \mathrm{CO}_{2}$ in $25-\mathrm{cm}^{2}$ Nunc ${ }^{T M}$ EasYFlask $^{T M}$ (Thermo Scientific) in a total volume of $10 \mathrm{ml}$ of DMEM-F12 medium complemented with 5\% FBS for each controls and treatments of $20 \mathrm{ng} / \mathrm{ml} \mathrm{TNF}-\alpha$ and 400, 800 and $1600 \mathrm{U} / \mathrm{ml}$ CAT respectively for $24 \mathrm{~h}$. The cells were harvested in TRIzol reagent (Invitrogen, Guangzhou, China) for total RNA isolation or stored at $-80^{\circ} \mathrm{C}$ for later use. Total RNA samples were purified by following the manufacturer's instruction and quantified using NanoDrop ND-1000 v3.3.0 (Thermo Fisher Scientific, Wilmington, DE, USA) with quality checked by gel electrophoresis. Using $1.0 \mu \mathrm{g}$ of total RNA for reverse transcription by the PrimeScript ${ }^{\circledR}$ RT Master Mix (TaKaRa, Shiga, Japan) and the transcripts were quantitatively measured by real-time RT-PCR using the All-in-One qPCR Mix (GeneCopoeia, Rockville, MD, USA) labeled with SYBR Green I dye, performed in 96well micro-plates using the following RT-PCR cycle: $95^{\circ} \mathrm{C}$ for 2 min followed by 40 cycles at $95^{\circ} \mathrm{C}$ for $5 \mathrm{sec}$ and $60^{\circ} \mathrm{C}$ for $15 \mathrm{sec}$. The quantities were normalized against the house-keeping gene of glyceraldehyde-3phosphate dehydrogenase (GAPDH) in the same sample. Relative mRNA expression levels were determined using the $2^{-\triangle(\triangle C T)}$ comparative method from the mean of triplicate treatments averaged from 3 replicate PCR reactions. The key factors of TNFR-1, FADD, TRADD, Cas-8, Cas-3 and MMP-13 involved in the extrinsic apoptotic pathway were examined as molecular markers in responses to the treatments of TNF- $\alpha$ and the antioxidant enzyme CAT. The sequences of the primers used for PCR reactions and the amplicons were summarized in Table 1.

Western blot assay for caspases

C28/I2 cells were treated exactly as for qRT-PCR. Chondrocytes were washed with $4^{\circ} \mathrm{C}$ pre-cooled 0.01M PBS (pH 7.2-7.3) by gentle agitation for 3 times and resuspended in RIPA Lysis and Extraction Buffer (Thermo Scientific), containing $25 \mathrm{mM}$ Tris-HCl pH 7.6, $150 \mathrm{mM} \mathrm{NaCl}, 1 \% \mathrm{NP}-40,1 \%$ sodium deoxycholate, $0.1 \%$ SDS with $1 \mathrm{mM}$ PMSF. Cells were lysed by incubation on ice for $30 \mathrm{~min}$ with occasional flicks followed by sonication using Sonics Vibra Cell ${ }^{T M}$ (Sonics \& Materials Inc., Newtown, CT, USA) for 25 sec (5 times of sonication for $5 \mathrm{sec}$ and stand on ice for $10 \mathrm{sec}$ ). The lysates were transferred to $1.5 \mathrm{ml}$ Eppendorf tube and centrifuged at $14,000 \mathrm{Xg}$ for $5 \mathrm{~min}$ at $4^{\circ} \mathrm{C}$. The supernatant was collected as a total protein sample for further analysis or stored at $-20^{\circ} \mathrm{C}$.

Total proteins from each cell lysate were separated by sodium dodecyl sulfate-polyacrylamide gel electrophoresis (SDS-PAGE) and subsequently transferred onto polyvinylidene difluoride (PVDF) membranes (88520, Pierce Biotechnology, Rockford, IL, USA) by Western blotting. Membranes were blocked for $1 \mathrm{~h}$ at room temperature in Tris-buffered saline with $0.01 \%$ Tween-20 (TBS-T) in 5\% skim milk powder solution, pH 7.4. The 1:250 diluted primary antibodies of rabbit Anti-CASP3 (p17) Antibody (BA2885-2, Boster, Wuhan, China) and rabbit polyclonal antibody against human $\beta$-Actin ( $\beta$-Actin (N-21), Santa Cruz Biotechnologies, Santa Cruz, CA, USA) were applied to the membranes respectively and incubated at $4^{\circ} \mathrm{C}$ overnight. The membranes were then incubated with 1:3000 diluted secondary antibody, the goat antirabbit IgG-HRP (Santa Cruz). The Caspase-8 (1C12) Mouse mAb (\#9746, Cell Signaling Technology, Danvers, MA, USA) was 1:750 diluted and applied to the membrane as for Cas-3, then incubated with the secondary antibody Goat Anti-Mouse IgG (g-chain specific) peroxidase conjugate (BA1050, Boster). Chemiluminescent light emission was detected using Clarity ${ }^{T M}$ Western ECL Substrate Kit (Bio-Rad, Hercules, CA, USA) and Pierce ${ }^{T M}$ ECL Western Blotting Substrate (Pierce Biotechnology, Rockford, IL, USA) according to the manufacturers' instructions respectively. Signals were captured and analyzed using the Image Lab (Beta 1) Version 3.0.1 Changelist 40296 software associated with Molecular Imager ${ }^{\circledR}$, ChemiDoc $^{T M}$ XRS+ Imaging System (Bio-Rad). 
Statistical analysis

Data are collected from $\geq 3$ independent experiments, means of which were used for analysis using the SPSS 22 (IBM SPSS Statistics, Chicago, IL, UAS). Differences between treatments and controls were determined by One-way ANOVA and presented as mean \pm standard deviation (bars). Differences with a $P$ $<0.05$ were statistically regarded as significant $(*), P<0.01$ as highly significant $\left({ }^{* *}\right)$.

\section{Results}

Effect of CAT on viability of human C28/I2 chondrocytes cultured in monolayer

The revived human immortalized cell line C28/I2 chondrocytes were cultured for passaging in the recommended medium in the conditions of $37^{\circ} \mathrm{C}, 5 \% \mathrm{CO}_{2}$ and become $\geq$ $80 \%$ confluence in 2-3 days. Most of the adherent cells appeared in clear healthy polygonal shapes with some of spindle-shaped and dividing cells (data not shown). Nine groups of C28/I2 cells were incubated in the medium containing 0 (control) and various dilutions of human CAT for $24 \mathrm{~h}$ and assayed by MTS (Fig. 1). The result showed an increased cell viability by CAT treatment at three doses of 800,1200 and $1600 \mathrm{U} / \mathrm{ml}$ of the range with some statistical significance and was useful for selection of CAT doses for further investigations. Lower and higher concentrations of CAT showed no effect on cell viability at all as compared to untreated cells.

Fig. 1. Characterization of CAT effect on viability of C28/ I2 chondrocytes cultured in monolayer. Viability of C28/I2 chondrocytes treated by a series diluted CAT in monolayer culture for $24 \mathrm{~h}$ and assayed by MTS. The cellular viability was generally maintained unchanged by increasing dosages of CAT. A statistically significant increment in cell viability was noted at dosage levels of 800 and $1200 \mathrm{U} / \mathrm{ml}^{* *}$ ), becoming weaker at the concentration of $1600 \mathrm{U} / \mathrm{ml}\left({ }^{*}\right)$. ${ }^{*} \mathrm{P}<0.05$; ** $\mathrm{P}<0.01$.

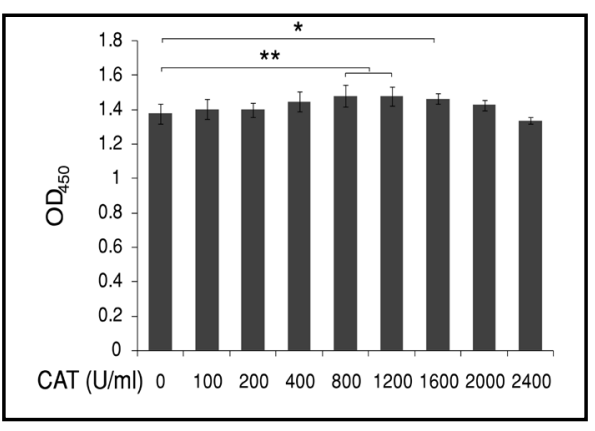

Fig. 2. Establishment of TNF- $\alpha$-induced apoptotic C28/ I2 chondrocytes cultured in monolayer. C28/I2 cells were treated with 3 selected c oncentrations (10, 20 and $30 \mathrm{ng} /$ $\mathrm{ml})$ of TNF- $\alpha$ and cultured for $24 \mathrm{~h}$. (A) Flow cytometry analysis of apoptosis using Annexin V/ PI staining. Plotting of apoptotic c ho nd ro c y t e s
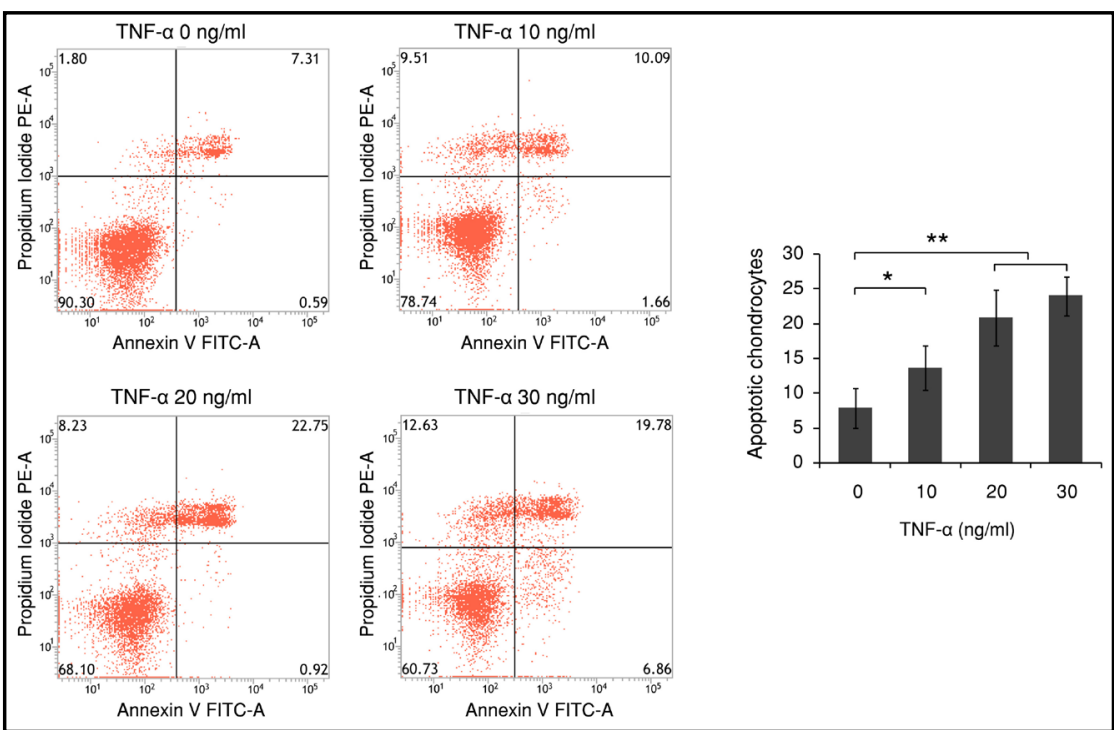

induced by 3

concentrations of TNF- $\alpha$ and untreated cells $(n=3) .10 \mathrm{ng} / \mathrm{ml}$ of TNF- $\alpha$ significantly $\left({ }^{*}\right)$ increased apoptosis of C28/I2 chondrocytes in culture while 20 and $30 \mathrm{ng} / \mathrm{ml}$ highly (**) induced apoptosis in treated cells. * $\mathrm{P}<0.05 ;{ }^{* *} \mathrm{P}<0.01$. 
Fig. 3. Effects of the p ro infla m matory cytokine TNF- $\alpha$ and antioxidant enzyme CAT on ROS level and mitochondrial membrane potential $\left(\Delta \psi_{\mathrm{m}}\right)$. (A) The level of intracellular ROS of $\mathrm{H}_{2} \mathrm{O}_{2}$ under the influence of TNF- $\alpha$ and CAT was detected by ROS-Glo ${ }^{\mathrm{TM}}$ $\mathrm{H}_{2} \mathrm{O}_{2}$ Assay plotted as Relative Luminescence Units (RLU). C28/I2 chondrocytes in culture for $24 \mathrm{~h}$ treated with $800 \mathrm{U} / \mathrm{ml}$ of CAT only showed no changes while treated with $20 \mathrm{ng} / \mathrm{ml}$ of TNF- $\alpha$ solely demonstrated a significant increment in intracellular $\mathrm{H}_{2} \mathrm{O}_{2}$ level $\left({ }^{* *}\right)$ compared to the untreated group. The simultaneous treatment by $20 \mathrm{ng} / \mathrm{ml} \mathrm{TNF}-\alpha$ and 3 selected concentrations of CAT $(400,800$ and $1600 \mathrm{U} / \mathrm{ml})$ massively ${ }^{* *}$ ) reduced the level of $\mathrm{H}_{2} \mathrm{O}_{2}$ in the cultured chondrocytes. (B) Examination of $\Delta \psi_{\mathrm{m}}$ using JC-1 staining and fluorescent spectrophotometry. The ratio of red fluorescent emission of cells with intact $\Delta \psi_{\mathrm{m}}$ against green fluorescent emission of cells lost $\Delta \psi_{\mathrm{m}}$ was plotted to represent the changes of $\Delta \psi_{\mathrm{m}}$. The cellular $\Delta \psi_{\mathrm{m}}$ in C28/I2 chondrocytes cultured for 24 $\mathrm{h}$ remained unchanged by $800 \mathrm{U} / \mathrm{ml}$ of CAT only and by $20 \mathrm{ng} / \mathrm{ml}$ of TNF- $\alpha$ solely, respectively compared to untreated cells. However, in the TNF- $\alpha$-affected cells cultured in monolayer, their cellular $\Delta \psi_{\mathrm{m}}$ were highly increased $\left(^{* *}\right)$ in a dosage-effective fashion by the 3 selected concentrations of CAT with a highest gained by the concentration of $1600 \mathrm{U} / \mathrm{ml}$. The figure is plotted by results of 3 independent experiments. ${ }^{* *} \mathrm{P}<0.01$.

\section{Apoptosis of C28/I2 chondrocytes induced by TNF- $\alpha$}

The apoptosis of C28/I2 chondrocytes induced by 3 concentrations of TNF- $\alpha$ for $24 \mathrm{~h}$. The induction of apoptosis was evaluated using Annexin V-FITC/PI double labeling assay by FCM (Fig. 2A), which is a representative plot of cell sorting showing apoptosis induced by the cytokine. The quantitative comparison of apoptotic cells in chondrocytes treated with 0 (control), 10, 20 and $30 \mathrm{ng} / \mathrm{ml}$ of TNF- $\alpha$ exhibited a dose-dependent induction (Fig. 2B). Treatment of the chondrocytes with $10 \mathrm{ng} / \mathrm{ml}$ of TNF- $\alpha$ significantly induced apoptosis $(P<0.05)$ while the induction was more significantly increased and remained at the same significance levels statistically $(P<0.01)$ when 20 and $30 \mathrm{ng} / \mathrm{ml}$ of TNF- $\alpha$ were used, not only confirming the induction of apoptosis in C28/I2 chondrocytes but also suggesting $20 \mathrm{ng} / \mathrm{ml}$ of TNF- $\alpha$ suitable for establishing apoptotic cell model in C28/I2 chondrocytes.

\section{CAT reduced the intracellular $\mathrm{H}_{2} \mathrm{O}_{2}$ level in C28/I2 chondrocytes}

The intracellular $\mathrm{H}_{2} \mathrm{O}_{2}$ level in cultured $\mathrm{C} 28 / \mathrm{I} 2$ chondrocytes was measured to evaluate the effect of CAT. The production of intracellular $\mathrm{H}_{2} \mathrm{O}_{2}$ in chondrocytes cultured for $24 \mathrm{~h}$ with $20 \mathrm{ng} / \mathrm{ml}$ of TNF- $\alpha$ remained unchanged compared to that in the untreated cells (Fig. $3 A)$. The intracellular $\mathrm{H}_{2} \mathrm{O}_{2}$ level in the cultured cells were highly reduced $(P<0.01)$ by the 3 selected dosages of CAT, including cells treated by $800 \mathrm{U} / \mathrm{ml}$ of CAT only. The $\mathrm{H}_{2} \mathrm{O}_{2}$ level was decreased to about $30 \%$ of the measurements for the untreated and TNF- $\alpha$-induced groups.

\section{Effect of CAT on $\Delta \psi_{m}$ changes in TNF- $\alpha$-treated C28/I2 chondrocytes}

Fluorospectrophotometry analysis of JC-1 stained cells showed the changes in $\Delta \psi_{\mathrm{m}}$ caused by TNF- $\alpha$ and CAT. The JC-1 form aggregates to emit red fluorescence in cells with intact $\Delta \psi_{\mathrm{m}}$ and remains in cytosol as monomers to emit green fluorescence in cells with collapsed $\Delta \psi_{\mathrm{m}}$. The emission of both red and green fluorescence was detected and red/green ratios in different groups were plotted (Fig. 3B). The $\Delta \psi_{\mathrm{m}}$ in untreated cells, the cells treated with $800 \mathrm{U} / \mathrm{ml}$ of CAT only and $20 \mathrm{ng} / \mathrm{ml}$ of TNF- $\alpha$ solely stayed at same level, and the double treatment by $400 \mathrm{U} / \mathrm{ml}$ of CAT and $20 \mathrm{ng} / \mathrm{ml}$ of TNF- $\alpha$ showed no effect on the level of $\Delta \psi_{\mathrm{m}}$ in 
the cultured chondrocytes (Fig. 3B). The $\Delta \psi_{\mathrm{m}}$ of the chondrocytes treated with $20 \mathrm{ng} / \mathrm{ml}$ of TNF- $\alpha$ was dramatically enhanced by $800 \mathrm{U} / \mathrm{ml}$ of CAT, which doubled the capacity (Fig. 3B) of $\Delta \psi_{\mathrm{m}}$ in the cells of untreated control, CAT treated only and $20 \mathrm{ng} / \mathrm{ml}$ of TNF- $\alpha$ combined with $400 \mathrm{U} / \mathrm{ml}$ of CAT. The cellular $\Delta \psi_{\mathrm{m}}$ in the cultured chondrocytes in the presence of TNF- $\alpha$ was further enhanced by a higher dose of CAT (1600 U/ml), exhibited an increment

Fig. 4. Effects of TNF- $\alpha$ and CAT on apoptosis of C28/I2 chondrocytes cultured in monolayer. C28/I2 cells were treated with 3 selected concentrations $(400,800$ and $1600 \mathrm{U} / \mathrm{ml}$ ) of CAT in the presence of $20 \mathrm{ng} /$ $\mathrm{ml}$ TNF- $\alpha$ in culture for 24 h. $800 \mathrm{U} / \mathrm{ml}$ of CAT was also tested in the absence of TNF- $\alpha$. (A) Flow cytometry analysis of apoptosis using Annexin V/PI staining. (B) Plotting of apoptotic chondrocytes of different treatments of CAT only or combinations of each 3 diluted CAT and TNF- $\alpha$, against untreated cells. The involvement of CAT only in the culture medium did not affect the cell growth while the TNF- $\alpha$ significantly $(* *)$ increased the cell apoptosis, which is about

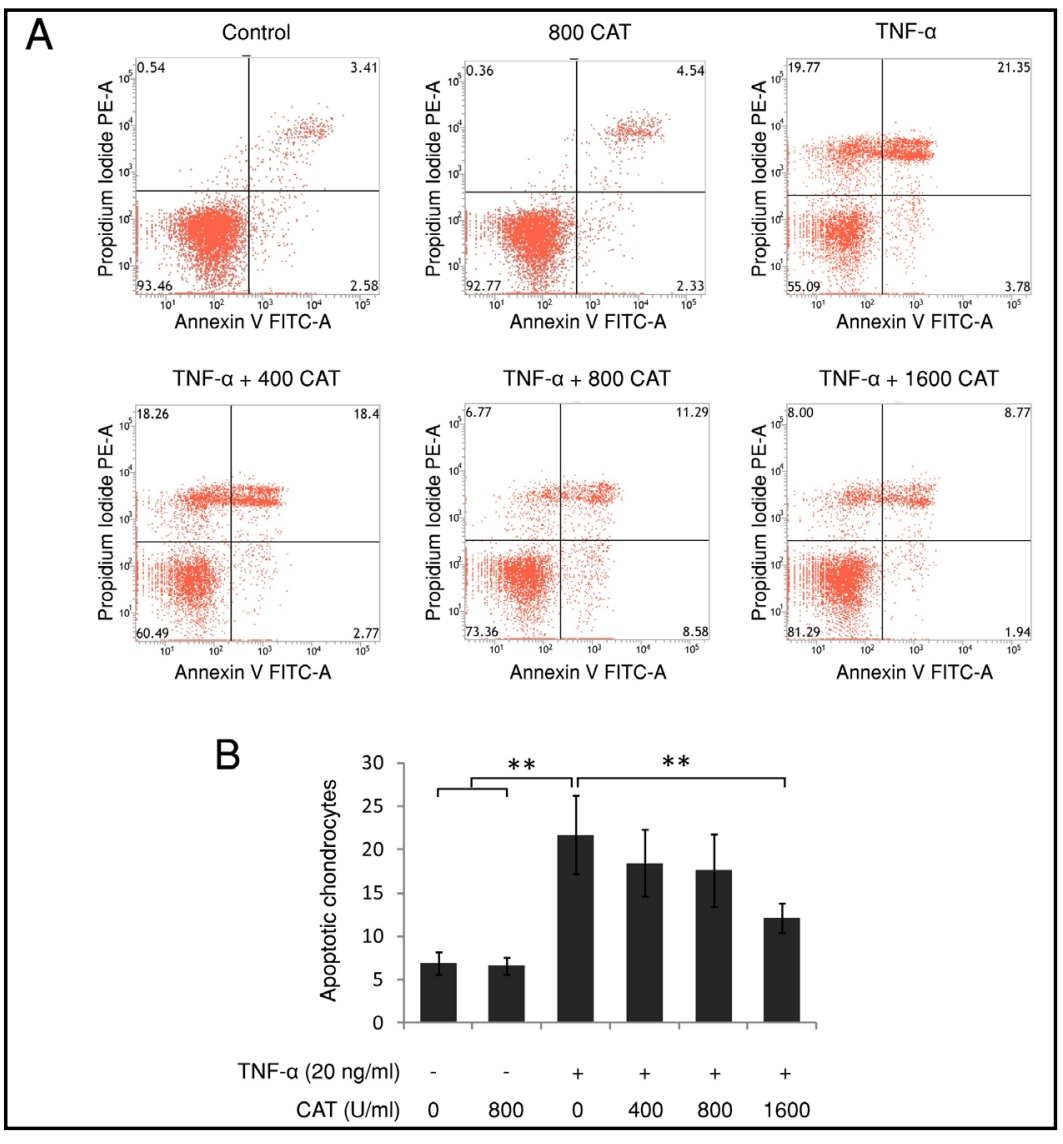

3 times of that in untreated cells. All 3 selected concentrations of CAT significantly (**) reduced apoptosis in TNF- $\alpha$-treated cells in a dose-dependent manner although not down to the level of untreated cells. The figure is plotted using results of 3 independent experiments. ${ }^{* *} \mathrm{P}<0.01$.

Fig. 5. Detection of morphological changes of chondrocytes treated with TNF- $\alpha$ and CAT in culture by acridine orange staining and CLSM. (A-C) The control chondrocytes showed normal oval-shaped nuclei with evenly stained double-stranded DNA in green (A) and nuclear RNA in red (B) with high integration as shown in the merged image (C). (D-F) The TNF- $\alpha$-treated chondrocytes exhibited apoptotic features of the condensed chromatin/nuclei with fragmentation (D) and irregular nuclear RNA staining with acidified compartments around the nuclei (E), and further displayed yellowish staining of early apoptotic nuclei (F). (G-I) The apoptotic effects of TNF- $\alpha$ on the chondrocytes were largely attenuated by $800 \mathrm{U} /$ $\mathrm{ml}$ of CAT. The figures are representatives of typical morphology from 3 independent experiments.

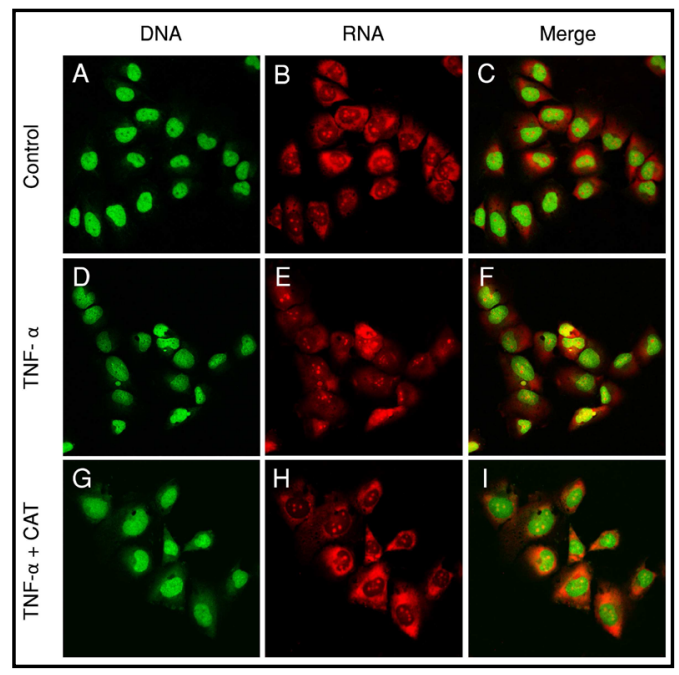


of about 2.5 times against the control groups and the $400 \mathrm{U} / \mathrm{ml}$ treated group (Fig. 3B). It appeared that CAT strengthened the cellular $\Delta \psi_{\mathrm{m}}$ in the TNF- $\alpha$-stimulated chondrocytes in monolayer culture in dose-dependent fashion.

\section{Effects of CAT on the TNF- $\alpha$-induced apoptosis of C28/I2 chondrocytes}

Apoptotic C28/I2 chondrocytes were induced using $20 \mathrm{ng} / \mathrm{ml}$ of TNF- $\alpha$ as determined in the establishment of cell model in monolayer culture for $24 \mathrm{~h}$, and the cells were evaluated by flow cytometry as in "Apoptosis of C28/I2 chondrocytes induced by TNF- $\alpha$ ". As expected, apoptosis of C28/I2 cells was induced by TNF- $\alpha$ treatment, indicating stabilized conditions of induction (Fig. 4A), in which the number of apoptotic cells is much greater than those detected in the untreated group. C28/I2 chondrocytes were cultured for $24 \mathrm{~h}$ in the presence of $20 \mathrm{ng} / \mathrm{ml} \mathrm{TNF-} \alpha$ and selected concentrations of CAT. The effect of CAT on TNF- $\alpha$-induced apoptosis in chondrocytes was also examined by Annexin V-FITC/PI staining and FCM assay. There was no difference in apoptosis between the untreated and CAT (800 $\mathrm{U} / \mathrm{ml}$ ) only treated chondrocytes, which remained at a low level while the TNF- $\alpha$-induced solely cells had $\approx 3$ times of apoptosis as detected in the untreated groups (Fig. 4A). The TNF- $\alpha$-induced apoptosis was significantly offset in a dose-dependent fashion by CAT in all 3 selected concentrations as shown in the quantitative plotting of the fluorescent intensities (Fig. 4B) although the attenuation did not restore the apoptotic rate.

Effects of CAT on morphological features of TNF- $\alpha$-induced apoptotic C28/I2 chondrocytes

The fluorochrome acridine orange differentially stains double- versus single-stranded nucleic acids. It intercalates into double stranded nucleic acids (DNA) to fluoresce green at $530 \mathrm{~nm}$ wavelength and interacts with single-stranded nucleic acids (mainly RNA)

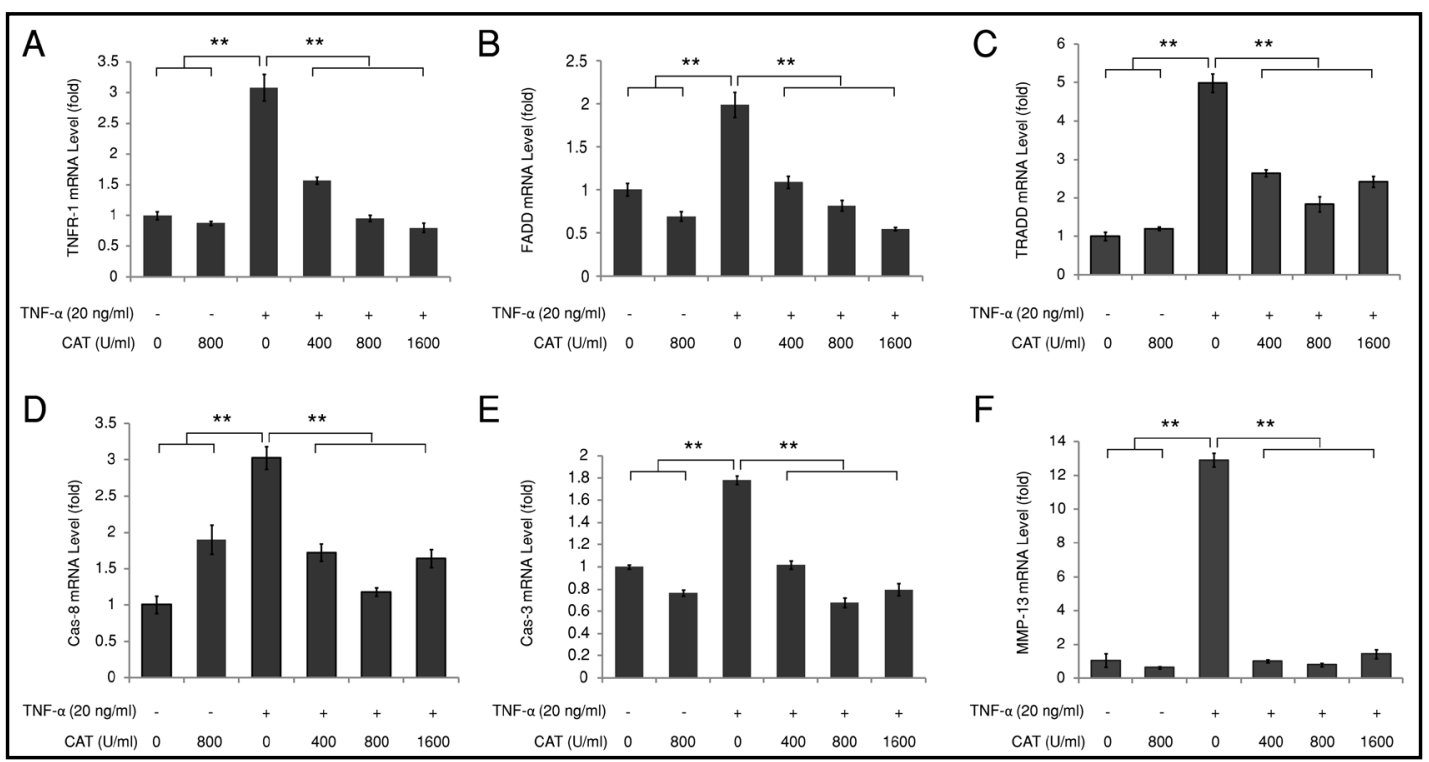

Fig. 6. qRT-PCR analysis of expression regulation of genes involved in cell death cascade and degeneration: TNFR-1 (A), FADD (B), TRADD (C), Cas-8 (D), Cas-3 (E) and MMP-13 (F). All these genes were highly upregulated $(* *)$ by TNF- $\alpha$, which were counteracted by CAT in a dose-dependent manner in the chondrocytes cultured in monolayer while the treatment of $800 \mathrm{U} / \mathrm{ml} \mathrm{CAT}$ only showed no regulatory effect compared to untreated control cells. CAT highly down-regulated the TNF- $\alpha$-upregulated Cas-8 expression with the most effective concentration of $800 \mathrm{U} / \mathrm{ml}$, halved the TNF- $\alpha$-stimulated Cas-8 expression (D), followed by a reduction of Cas-3 in a similar fashion (E). It is noteworthy that the expression of "dead" mediator of TRADD (C) and the "cartilaginous" degenerative enzyme MMP-13 (F) was massively elevated by TNF- $\alpha$, about 6 times and 12 times of their respective controls and were offset by all 3 selected doses of CAT. The figure is summarized from results of 3 independent experiments. ${ }^{* *} \mathrm{P}<0.01$. 
Fig. 7. Protein level of apoptotic enzymes of Cas-8 (A) and Cas-3 (B) was regulated by TNF- $\alpha$ and CAT as examined by Western blot analysis against the house-keeping cytoskeletal protein $\beta$-actin. In the given culturing conditions, CAT only treatment $(800 \mathrm{U} / \mathrm{ml})$ had a little effect on protein level of both Cas-8 and Cas- 3 but TNF- $\alpha$ only treatment highly upregulated (**) the level of these apoptotic enzymes. TNF- $\alpha$ treatment increased as almost 4 times much $\left(^{* *}\right)$ as that of Cas-8 (A) in untreated cells, and the Cas-3 protein level was also highly (**) elevated (B) by the apoptosis-inducing cytokine. These effects of TNF- $\alpha$ on chondrocytes were attenuated by all 3 doses of CAT in dose-effective fashion with further offsetting more than the level of untreated cells for the executional apoptotic enzyme Cas-3 (B). The figure represents results of 3 independent experiments. ${ }^{*} \mathrm{P}<0.05$; ${ }^{* *} \mathrm{P}<0.01$.

to generate condensation and agglomeration of the dye that emit orange-red at $640 \mathrm{~nm}$. Apoptotic cells show loss of cell volume [31], blebbing of plasma membrane, condensed chromatin around nucleus or condensed entire nucleus [32], with activated lysosomes and degenerating organelles, which acidify the intracellular compartments [33] resulting in morphological changes that can be revealed by differential staining of acridine orange [34]. The control chondrocytes showed normal oval-shaped nuclei with evenly stained doublestranded DNA in green (Fig. 5A) and nuclear RNA in red (Fig. 5B) highly integrated as shown in the merged image under CLSM (Fig. 5C). The chondrocytes treated with TNF- $\alpha$ showed apoptotic features of the condensed chromatin/nuclei with fragmentation (Fig. 5D) and irregular nuclear RNA staining with acidified compartments around the nuclei (Fig. 5E), and further displayed yellowish staining of early apoptotic nuclei (Fig. 5F). The effects of TNF- $\alpha$ on the chondrocytes were largely attenuated by the treatment of $800 \mathrm{U} / \mathrm{ml}$ of CAT (Fig. 5G, $5 \mathrm{H}$ and $5 \mathrm{I})$.

Effects of CAT on the expression of key death mediators activated by TNF- $\alpha$ in C28/I2 chondrocytes

The expression of genes coding for the inflammatory cytokine TNF- $\alpha$, its receptor TNFR1 and associated dead mediators of TRADD and FADD, the apoptotic enzymes of Cas- 8 and Cas-3, and the matrix degrading enzyme MMP-13, were examined using qRT-PCR. Compared to the untreated cells, the expression of these genes was highly up-regulated $(P<0.01)$ in the C28/I2 chondrocytes cultured in monolayer by TNF- $\alpha(20 \mathrm{ng} / \mathrm{ml})$ while either up- or down-regulated $(P>0.05)$ by CAT $(800 \mathrm{U} / \mathrm{ml})$ treatment only at level of untreated cells (Fig. $6)$. The highly up-regulated expression of these marker genes in TNF- $\alpha$-treated groups was dosage-effectively downregulated by CAT of 3 selected doses, some of which were attenuated to the levels of untreated controls and the rests were offset further lesser than untreated cells (Fig. 6), such as TNFR-1 (Fig. 6A), FADD (Fig. 6B), Cas-3 (Fig. 6D and MMP-13 (Fig. 6F). The concentration of $800 \mathrm{U} / \mathrm{ml}$ CAT was efficient and, in some cases, are more effective in diminishing the TNF- $\alpha$ stimulation. It is noteworthy that TRADD and MMP-13 were most effectively stimulated genes by TNF- $\alpha$, which were massively elevated, about 6 times Fig. 6C) and 12 times (Fig. 6F) of their untreated control cells respectively and counteracted to untreated expression levels by all three selected doses of CAT. 


\section{Cellular Physiology Cell Physiol Biochem 2018;49:2427-2442

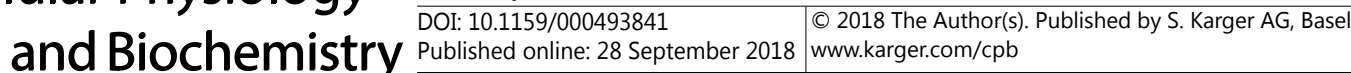 \\ Li et al.: Catalase Boosts Viability of Chondrocytes in Culture}

Effects of CAT on protein level of caspases activated by TNF- $\alpha$ in C28/I2 chondrocytes

To determine the expression of apoptotic proteases in the death pathway at the posttranscriptional level, the key effector of Cas- 8 and the downstream executor Cas- 3 were detected by Western blot analysis using the cytoskeleton protein $\beta$-actin as an internal control. In the given culturing conditions, CAT only treatment $(800 \mathrm{U} / \mathrm{ml})$ had a little effect on the protein level of both Cas- 8 and Cas-3 but TNF- $\alpha$ only treatment highly upregulated $(P<0.01)$ the level of these apoptotic enzymes (Fig. 7). TNF- $\alpha$ treatment increased as almost 4 times much $(P<0.01)$ as that of Cas-8 in untreated cells (Fig. 7A), and the Cas-3 protein level was also highly $(P<0.01)$ elevated by the apoptosis-inducing cytokine (Fig. 7B). These effects of TNF- $\alpha$ on chondrocytes were attenuated by all 3 doses of CAT in dose-effective fashion with further offsetting more than the level of untreated cells for the executional apoptotic enzyme Cas-3 (7B).

\section{Discussion}

High viability of chondrocytes is essentially important for cellular functions and readily affected by various factors in vivo and in vitro. Chondrocytes are physiologically distributed in the ECM of cartilage $[2,3,35]$, sense the stimulatory signals in milieu through their interaction with ECM and respond by secretions to govern the biological processes of physiologic remodeling and reparative regeneration in pathologic conditions $[5,6]$. Chondrocytes are vulnerable to damages caused by mechanical factors and biochemical stimuli in vivo [12, $36,37]$ and changes in microenvironmental conditions in vitro [38-40], which induce cell death and phenotypic alteration. Maintaining the chondrocytic viability and function, and preventing the cells from apoptosis would be superbly important for cartilage regeneration essential for damage repair and for cell-based therapies, such as ACI [2, 41], which require large number of functional chondrocytes. One of the most critical effectors of chondrocyte growth and function is $\mathrm{H}_{2} \mathrm{O}_{2}$, a relatively stable product of antioxidant scavenging system from endogenous and exogenous oxidative stresses [42], which makes great impact on the cell fate, e.g. causing inflammation and apoptosis. The antioxidant enzyme CAT specifically participates in the process of converting $\mathrm{H}_{2} \mathrm{O}_{2}$ to $\mathrm{H}_{2} \mathrm{O}+\mathrm{O}_{2}$, and plays a pivotal role for maintenance of redox homeostasis [43]. Amongst immortalized human chondrocyte cell lines, C28/I2 chondrocytes exhibit highest level of matrix metabolic genes, which makes them a preferable choice for study of metabolic activity and modulation [44]. In this study, the effect of CAT on the apoptosis was investigated using TNF- $\alpha$-treated cell model of C28/ I2 chondrocytes.

CAT scavenged intracellular ROS generated by the culture system and enhanced cellular $\Delta \psi_{\mathrm{m}}$ while TNF- $\alpha$ induced apoptotic features in C28/I2 chondrocytes cultured in monolayer. The cultured C28/I2 cells were morphologically healthy and the viability of those cells cultured for $24 \mathrm{~h}$, as shown by MTS assays, in the presence of 3 concentrations of CAT [800, $1200(P<0.01)$ and $1600(P<0.05) \mathrm{U} / \mathrm{ml}$ in the serial dilution range] with a notable significance (Fig. 1), which was used to assist with the selection of CAT dosages for further experiments. However, these "statistically significant" variations of the cell viability were proportionally too small compared to their full magnitude for each group $(\approx 4 \%$ of the value for the most variable ones) to be biological meaningful. Therefore, CAT by itself was not considered to be effective on cell viability in chondrocytes cultured in monolayer. Furthermore, $800 \mathrm{U} / \mathrm{ml} \mathrm{CAT}$ showed no effects on cellular $\Delta \psi_{\mathrm{m}}$ (Fig. 3B), apoptosis (Fig. 4), the expression of most of the key apoptotic genes (Fig. 6), including TNFR-1 (Fig. 6A), TRADD (Fig. 6C), Cas-3 (Fig. 6D) and MMP-13 (Fig. 6F) with variables $(P>0.05)$ observed for FADD (Fig. 6B) and Cas-8 (Fig. 6E). Western blot analysis also revealed unchanged Cas-8 (Fig. 7A) and Cas-3 (Fig. 7B) proteins by CAT. On the contrary, TNF- $\alpha$ exerted its effects on the metabolism of C28/I2 chondrocytes cultured in monolayer, increased apoptosis by 3 doses in a dose-dependent manner (Fig. 2), which generated a stable apoptotic cell model for clarifying the therapeutic effect of CAT in the study. In human C28/I2 chondrocytes cultured in monolayer, TNF- $\alpha(20 \mathrm{ng} / \mathrm{ml})$ was

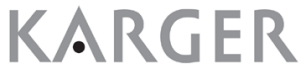


found to massively increase the expression of the pro-apoptotic molecular markers at both the transcriptional (Fig. 6) and translational (Fig. 7) levels, which attributed to the ultimately increased cell death as detected by FCM (Fig. 4). Although a significantly increased $\mathrm{H}_{2} \mathrm{O}_{2}$ level $(P<0.01)$ was detected in the TNF- $\alpha$-treated cells compared to the untreated control (Fig. 3A) by a small magnitude $(<4 \%$ of the measurements), it would not be biologically significance. TNF- $\alpha$ by itself did not affect the intracellular ROS level and the cellular $\Delta \psi_{\mathrm{m}}$ in cultured chondrocytes in vitro (Fig. 3B).

The CAT treatments overwhelmingly reduced ROS generated in the culture system and rectified the effects of TNF- $\alpha$ stimulation in chondrocytes. It appeared that high level of intracellular ROS was largely generated by the cell culture system rather stimulated by TNF- $\alpha$, which caused little variations compared to the large magnitude of measurements (Fig. 3A). The comparatively high level of ROS would be excessive for chondrocytes that normally reside in a physiologically hypoxic condition, and causes damages, especially to mitochondrial function $[24,25]$, resulting in reduction of DNA integrity and damage repair and leading to cell death $[45,46]$. The mitochondria are a "power station" of the cell, participate in the process of signal transduction and in cellular activities, including sensing the redox homeostasis [20] and producing non-enzymatic and enzymatic antioxidants, but mitochondria are generally devoid of CAT [47] for defending from oxidative stress. In fact, the 3 dosages of CAT provided enough activity in this study capable of scavenging systematic ROS by bringing the intracellular $\mathrm{H}_{2} \mathrm{O}_{2}$ to a significant low level of $<1 / 3$ of that in untreated control cells (Fig. 3A), regardless of TNF- $\alpha$ treatments. The 3 dosages of CAT, in conjunction with TNF- $\alpha$, also enhanced cellular $\Delta \psi_{\mathrm{m}}$ in a dose-dependent manner in the cultured chondrocytes (Fig. 3B) since the $\Delta \psi_{\mathrm{m}}$ were maintained similar levels in chondrocytes of untreated, treated with $800 \mathrm{U} / \mathrm{ml}$ CAT only, treated with $20 \mathrm{ng} / \mathrm{ml}$ TNF- $\alpha$ only and treated with combination of $400 \mathrm{U} / \mathrm{ml} \mathrm{CAT}$ and $20 \mathrm{ng} / \mathrm{ml}$ TNF- $\alpha$, but were strengthened by treatments of higher doses of CAT in the TNF- $\alpha$-treated groups (Fig. 3B). The increased cellular $\Delta \psi_{\mathrm{m}}$ in 800 and 1600 $\mathrm{U} / \mathrm{ml}$ CAT-treated groups were respectively $\approx 2$ times and $>2.5$ times of that detected in control cells. These effects collectively ameliorated morphological features at cellular level (Fig. 5), down-regulated expression of genes involved in extrinsic apoptosis pathway at transcriptional level (Fig. 6) and protein level (Fig. 7) in a dosage effective fashion, eventually resulted in a reduced apoptosis (Fig. 4). CAT scavenged intracellular ROS in chondrocytes exposed to a more oxidative culturing system compared to the hypoxic microenvironment in vivo, regardless of the presence of stimuli such as TNF- $\alpha$, and enhanced cellular $\Delta \psi_{\mathrm{m}}$ with a dosage effective fashion in the presence of TNF- $\alpha$. It would be of great scientific interest to elucidate the effect of CAT doses $>1600 \mathrm{U} / \mathrm{ml}$ on the cultured chondrocytes with the expectation of a higher level of enhanced $\Delta \psi_{\mathrm{m}}$ to promote cellular viability. Further, a future investigation on the effect of superoxide dismutases (SODs) in conjunction with CAT would certainly enrich our understanding and contribute to the enhancement of viability by wholly redox balancing, since SODs catalyze dismutation of superoxide $\left(\mathrm{O}_{2}^{-}\right)$into oxygen and $\mathrm{H}_{2} \mathrm{O}_{2}$ that are readily cleaned by CAT $[22,23]$.

The anti-apoptotic effects of CAT on chondrocytes, along with the mechanisms, are intriguingly important not only for the maintenance of cell viability essential for in vivo cartilage regeneration in cases of physiologic remodeling and pathologic repairing, but also for obtaining large number of chondrocytes cultured ex vivo required for cell-based therapeutic approaches by tissue engineering. Accumulated evidence demonstrated that passaged chondrocytes change their metabolic behavior, especially altering their gene expression profiles and dedifferentiating to fibroblastic status of decreased collagen type II and aggrecan, and increased collagen type I [48, 49]. Since activities of cells in culture are largely under the influence of media and complemented bioactive agents, the differentiation phenotype of in vitro expanded chondrocytes can be achieved experimentally $[34,50]$. However, attempts were made in this study to investigate the effect of CAT on the dedifferentiation markers of the cultured C28/I2 cells, which could not be resolved (data not shown) because the chondrocytes reportedly are deprived of expression of genes involved in matrix synthesis and turnover, including collagen type I and II, and aggrecan, in the process 


\section{Cellular Physiology Cell Physiol Biochem 2018;49:2427-2442 and Biochemistry \begin{tabular}{l|l} 
DOI: 10.1159/000493841 & $\begin{array}{l}\text { O } 2018 \text { The Author(s). Published by S. Karger AG, Basel } \\
\text { www.karger.com/cpb }\end{array}$
\end{tabular} \\ Li et al.: Catalase Boosts Viability of Chondrocytes in Culture}

of immortalization favoring proliferation and cycling [44]. The ability of CAT in maintaining differentiation phenotype of chondrocytes is of scientific significance, particularly as a potential therapeutic agent for cartilage regeneration, which remain to be studied using appropriate cells.

CAT prevented TNF- $\alpha$-induced apoptosis of C28/I2 chondrocytes through, at least in part, interfering TNF/TNFR mediated extrinsic apoptosis pathway. Cell apoptosis is evoked by multiple pathways but mainly the intrinsic and extrinsic signaling cascades, both of which result in activation of executor caspases through the initiator caspase Cas-8 [51]. The association of TNF- $\alpha$ with TNFR [12] on the cell surface recruits TRADD, FADD to form the cytosolic platform of DISC as a ligand-dependent transmembrane signaling receptor [52] that initiates inflammation [16] and apoptosis cascade $[17,18]$. DISC provokes the Cas-8 to activate Cas-3, which sabotages a range of cytoplasmic proteins and dismantles chromatin and nucleoplasmic proteins in the nucleus, eventually resulting in apoptosis. The TNF- $\alpha$ was chosen to induce apoptotic C28/I2 cells in this study since it has been showed similar or synergistic effects of IL-1 $\beta$ [53] and elevated by IL-1 $\beta$-treated cells [15] with higher efficacy to activate caspases by a different mechanism in human chondrocytes [54]. This study focused on the effect of CAT on death factors of extrinsic cascade in TNF- $\alpha$-treated C28/I2 chondrocytes.

The expression level of genes encoding the key dead factors/mediators of TNFR-1, FADD, TRADD, Cas-8 and Cas-3, and MMP-13, a matrix-degrading enzyme with predominant action on type II collagen [55], from the extrinsic apoptosis pathway, and the protein level of the key caspases of Cas- 8 and Cas- 3 were all increased in the TNF- $\alpha$-treated C28/I2 chondrocytes cultured in monolayer (Fig. $6 \& 7$ ). These expressions were largely not affected by CAT (800 $\mathrm{U} / \mathrm{ml}$ ) only treatments. CAT counteracted the TNF- $\alpha$-stimulated expression of these genes, some of which were restored to the level of control cells while others were even further reduced (Fig. 6) mostly with dosage effect. The regulatory effect of CAT on induced Cas-8 and Cas-3 was also reflected at the protein level as shown by Western blot (Fig. 7), in which all 3 selected doses of CAT significantly attenuated the increased Cas- 8 and Cas- 3 proteins against the TNF- $\alpha$ stimulated groups (Fig. 7) respectively, and further lowered Cas-3 protein than its untreated control (Fig. 7B). TNF- $\alpha$ significantly increased Cas-8 gene expression (Fig. 6D) resulted in $>3.5$ folds' increment of Cas-8 proteins (Fig. 7A) in treated C28/I2 cells, which would be facilitating the activation of extrinsic pathway. These results indicated that TNF- $\alpha$ was highly provocative to the extrinsic apoptosis cascade, stimulated expression of key factors composing of DISC and the apoptotic enzymes, supporting the caspasedependent nature of TNF- $\alpha$ in induction of cell death [54]. Based on the evidence that CAT counteracted the upregulation of key players of TNF/TNFR mediated death cascade and that CAT ultimately attenuated TNF- $\alpha$-induced chondrocyte apoptosis, this study supports that CAT inhibits apoptosis in TNF- $\alpha$-induced chondrocytes through blocking off the death cascade [17].

However, the determination of cell fate is a complicated cellular and molecular process in the intricate biological networks. High level of activated Cas-8 at DISC provokes executor caspases directly, leading to apoptosis by the extrinsic pathway, but relatively low level of activated Cas- 8 could activate executor caspases through intrinsic pathway by permeabilized mitochondria with the assistance of pro-apoptotic proteins of Bcl-2 family [18], which is also regulated by small non-coding RNA molecules (miRNAs) [56, 57]. Damages to mitochondria and their functions by factors and resulting products, such as ROS, increase the membrane permeabilization allowing the release of cytochrome $\mathrm{c}$ to initiate the formation of apoptosome [52], which, in turn, activate caspases, leading to cell apoptosis. As evidenced in this study, CAT massively reduced the intracellular $\mathrm{H}_{2} \mathrm{O}_{2}$ in chondrocytes grown in the culturing system (Fig. 3A) and effectively increased $\Delta \psi_{\mathrm{m}}$ in TNF- $\alpha$-treated chondrocytes (Fig. 3B), it would enhance the mitochondrial function and inhibit cell apoptosis, ultimately resulting in promoted cell viability. These results implicated the high level of insisting oxidative stress for chondrocytes in the culture system regardless of additional stimuli. The oxidative stress 


\section{Cellular Physiology Cell Physiol Biochem 2018;49:2427-2442 and Biochemistry Published \begin{tabular}{l|l} 
DOI: 10.1159/000493841 & (c) 2018 The Author(s). Published by S. Karger AG, Basel \\
www.karger.com/cpb
\end{tabular} \\ Li et al.: Catalase Boosts Viability of Chondrocytes in Culture}

would probably activate other "death" signals, including the intrinsic death cascade, which is to be investigated along with the protective actions of the antioxidant enzyme CAT.

\section{Conclusion}

In conclusion, CAT effectively reduced intracellular ROS raised by the cell culture system, attenuated adverse effects of TNF- $\alpha$ on cultured chondrocytes to enhance the cellular $\Delta \psi_{\mathrm{m}}$ dependently, strengthen cellular features, rectify upregulated factors/mediators of extrinsic pathway of cell death and apoptotic caspases. These actions of CAT ultimately result in reduced cell apoptosis and promote the antioxidant as a potential anti-apoptotic agent in promoting cell viability, particularly for obtaining large number of viable chondrocytes in culture ex vivo essential to cell-based therapies of cartilage repair by tissue engineering.

\section{Acknowledgements}

The authors thank Peihong Liang, Guangzhou Institute of Traumatic Surgery, Guangzhou Red Cross Hospital, Jinan University School of Medicine for her technical assistance. This work was financially supported by Guangzhou 121 Echeloned Promoting Project for Talented Scientists [SRF (2009) 149], the research grants of Guangdong Provincial Department of Science and Technology (2014A020211001 and 2016A050503003), and the special research project (201607010009) granted by Guangzhou Science Technology and Innovation Commission.

\section{Disclosure Statement}

The authors declare to have no conflict of interests.

\section{References}

1 Oldershaw RA: Cell sources for the regeneration of articular cartilage: the past, the horizon and the future. Int J Exp Pathol 2012;93:389-400.

2 Bora FW, Jr., Miller G: Joint physiology, cartilage metabolism, and the etiology of osteoarthritis. Hand Clin 1987;3:325-336.

-3 Archer CW, Francis-West P: The chondrocyte. Int J Biochem Cell Biol 2003;35:401-404.

4 Martin JA, Buckwalter JA: The role of chondrocyte senescence in the pathogenesis of osteoarthritis and in limiting cartilage repair. J Bone Joint Surg Am 2003;85-A Suppl 2:106-110.

5 Mobasheri A, Carter SD, Martin-Vasallo P, Shakibaei M: Integrins and stretch activated ion channels; putative components of functional cell surface mechanoreceptors in articular chondrocytes. Cell Biol Int 2002;26:1-18.

6 Millward-Sadler SJ, Salter DM: Integrin-Dependent Signal Cascades in Chondrocyte Mechanotransduction. Annals of Biomedical Engineering 2004;32:435-446.

7 Sandell LJ, Aigner T: Articular cartilage and changes in arthritis. An introduction: cell biology of osteoarthritis. Arthritis Res 2001;3:107-113.

8 Grande DA, Pitman MI, Peterson L, Menche D, Klein M: The repair of experimentally produced defects in rabbit articular cartilage by autologous chondrocyte transplantation. J Orthop Res 1989;7:208-218.

-9 Brittberg M, Lindahl A, Nilsson A, Ohlsson C, Isaksson 0, Peterson L: Treatment of deep cartilage defects in the knee with autologous chondrocyte transplantation. N Engl J Med 1994;331:889-895.

10 Brittberg M: Autologous chondrocyte implantation--technique and long-term follow-up. Injury 2008;39 Suppl 1:S40-49. 


\section{Cellular Physiology Cell Physiol Biochem 2018:49:2427-2442

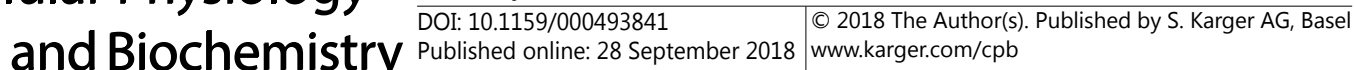

11 Otsuki S, Brinson DC, Creighton L, Kinoshita M, Sah RL, D’Lima D, Lotz M: The effect of glycosaminoglycan loss on chondrocyte viability: a study on porcine cartilage explants. Arthritis Rheum 2008;58:1076-1085.

12 Wojdasiewicz P, Poniatowski LA, Szukiewicz D: The Role of Inflammatory and Anti-Inflammatory Cytokines in the Pathogenesis of Osteoarthritis. Mediators Inflamm 2014;2014:1-19.

13 Papathanasiou I, Michalitsis S, Hantes ME, Vlychou M, Anastasopoulou L, Malizos KN, Tsezou A: Molecular changes indicative of cartilage degeneration and osteoarthritis development in patients with anterior cruciate ligament injury. BMC Musculoskelet Disord 2016;17:21.

$\checkmark 14$ Kapoor M, Martel-Pelletier J, Lajeunesse D, Pelletier J-P, Fahmi H: Role of proinflammatory cytokines in the pathophysiology of osteoarthritis. Nat Rev Rheumatol 2011;7:33-42.

-15 Ikejima T, Okusawa S, Ghezzi P, van der Meer JW, Dinarello CA: Interleukin-1 induces tumor necrosis factor (TNF) in human peripheral blood mononuclear cells in vitro and a circulating TNF-like activity in rabbits. J Infect Dis 1990;162:215-223.

16 Saperstein S, Chen L, Oakes D, Pryhuber G, Finkelstein J: IL-1beta augments TNF-alpha-mediated inflammatory responses from lung epithelial cells. J Interferon Cytokine Res 2009;29:273-284.

17 Qin J, Shang L, Ping AS, Li J, Li XJ, Yu H, Magdalou J, Chen LB, Wang H: TNF/TNFR signal transduction pathway-mediated anti-apoptosis and anti-inflammatory effects of sodium ferulate on IL-1beta-induced rat osteoarthritis chondrocytes in vitro. Arthritis Res Ther 2012;14:R242.

18 Barnhart BC, Alappat EC, Peter ME: The CD95 type I/type II model. Semin Immunol 2003;15:185-193.

19 Blaser H, Dostert C, Mak TW, Brenner D: TNF and ROS Crosstalk in Inflammation. Trends Cell Biol 2016;26:249-261.

20 Waypa GB, Smith KA, Schumacker PT: 02 sensing, mitochondria and ROS signaling: The fog is lifting. Mol Aspects Med 2016;47-48:76-89.

-21 Bae YS, Oh H, Rhee SG, Yoo YD: Regulation of reactive oxygen species generation in cell signaling. Mol Cells 2011;32:491-509.

22 Handy DE, Loscalzo J: Redox Regulation of Mitochondrial Function. Antioxidants \& Redox Signaling 2012;16:1323-1367.

23 Foyer CH, Noctor G: Tansley Review No. 112. New Phytologist 2000;146:359-388.

-24 Lonn E, Bosch J, Yusuf S, Sheridan P, Pogue J, Arnold JM, Ross C, Arnold A, Sleight P, Probstfield J, Dagenais GR: Effects of long-term vitamin E supplementation on cardiovascular events and cancer: a randomized controlled trial. Jama 2005;293:1338-1347.

25 Wiernsperger NF: Oxidative stress: the special case of diabetes. Biofactors 2003;19:11-18.

26 Rai P, Parrish M, Tay IJ, Li N, Ackerman S, He F, Kwang J, Chow VT, Engelward BP: Streptococcus pneumoniae secretes hydrogen peroxide leading to DNA damage and apoptosis in lung cells. Proc Natl Acad Sci U S A 2015;112:E3421-3430.

-27 Kim SJ, Cheresh P, Jablonski RP, Morales-Nebreda L, Cheng Y, Hogan E, Yeldandi A, Chi M, Piseaux R, Ridge K, Michael Hart C, Chandel N, Scott Budinger GR, Kamp DW: Mitochondrial catalase overexpressed transgenic mice are protected against lung fibrosis in part via preventing alveolar epithelial cell mitochondrial DNA damage. Free Radic Biol Med 2016;101:482-490.

28 Mullineaux PM, Karpinski S, Baker NR: Spatial dependence for hydrogen peroxide-directed signaling in light-stressed plants. Plant Physiol 2006;141:346-350.

-29 Goldring MB, Birkhead JR, Suen LF, Yamin R, Mizuno S, Glowacki J, Arbiser JL, Apperley JF: Interleukin-1 beta-modulated gene expression in immortalized human chondrocytes. J Clin Invest 1994;94:2307-2316.

-30 Reers M, Smith TW, Chen LB: J-aggregate formation of a carbocyanine as a quantitative fluorescent indicator of membrane potential. Biochemistry 1991;30:4480-4486.

31 Lockshin RA, Beaulaton J: Cell death: questions for histochemists concerning the causes of the various cytological changes. Histochem J 1981;13:659-666.

-32 Wyllie AH, Kerr JF, Currie AR: Cell death: the significance of apoptosis. Int Rev Cytol 1980;68:251-306.

33 Kapuscinski J, Darzynkiewicz Z: Condensation of nucleic acids by intercalating aromatic cations. Proc Natl Acad Sci U S A 1984;81:7368-7372.

34 Yang X, Liu S, Li S, Wang P, Zhu W, Liang P, Tan J, Cui S: Salvianolic acid B regulates gene expression and promotes cell viability in chondrocytes. J Cell Mol Med 2017;21:1835-1847.

35 Milner PI, Wilkins RJ, Gibson JS: Cellular Physiology of Articular Cartilage in Health and Disease; in (Rothschild BM, ed) Principles of Osteoarthritis- Its Definition, Character, Derivation and Modality-Related Recognition. IN TECH, 2012, vol. 10.5772/28379p.^pp. 


\section{Cellular Physiology Cell Physiol Biochem 2018:49:2427-2442 and Biochemistry \begin{tabular}{l|l} 
DOI: 10.1159/000493841 & (c) 2018 The Author(s). Published by S. Karger AG, Basel \\
www.karger.com/cpb
\end{tabular}

36 Kapoor M, Martel-Pelletier J, Lajeunesse D, Pelletier JP, Fahmi H: Role of proinflammatory cytokines in the pathophysiology of osteoarthritis. Nat Rev Rheumatol 2011;7:33-42.

-37 Fortier LA, Barker JU, Strauss EJ, McCarrel TM, Cole BJ: The role of growth factors in cartilage repair. Clin Orthop Relat Res 2011;469:2706-2715.

-38 Lin Z, Fitzgerald JB, Xu J, Willers C, Wood D, Grodzinsky AJ, Zheng MH: Gene expression profiles of human chondrocytes during passaged monolayer cultivation. J Orthop Res 2008;26:1230-1237.

-39 Benya PD, Shaffer JD: Dedifferentiated chondrocytes reexpress the differentiated collagen phenotype when cultured in agarose gels. Cell 1982;30:215-224.

-40 Stokes DG, Liu G, Dharmavaram R, Hawkins D, Piera-Velazquez S, Jimenez SA: Regulation of type-II collagen gene expression during human chondrocyte de-differentiation and recovery of chondrocyte-specific phenotype in culture involves Sry-type high-mobility-group box (SOX) transcription factors. Biochem J 2001;360:461-470.

41 Musumeci G, Loreto C, Leonardi R, Castorina S, Giunta S, Carnazza ML, Trovato FM, Pichler K, Weinberg AM: The effects of physical activity on apoptosis and lubricin expression in articular cartilage in rats with glucocorticoid-induced osteoporosis. J Bone Miner Metab 2013;31:274-284.

42 Wang P, Zhang F, He Q, Wang J, Shiu HT, Shu Y, Tsang WP, Liang S, Zhao K, Wan C: Flavonoid Compound Icariin Activates Hypoxia Inducible Factor-1alpha in Chondrocytes and Promotes Articular Cartilage Repair. PLoS One 2016;11:e0148372.

43 Shapiro HM: Cell membrane potential analysis. Methods Cell Biol 1990;33:25-35.

44 Finger F, Schorle C, Zien A, Gebhard P, Goldring MB, Aigner T: Molecular phenotyping of human chondrocyte cell lines T/C-28a2, T/C-28a4, and C-28/I2. Arthritis Rheum 2003;48:3395-3403.

45 Gibson BW: The human mitochondrial proteome: oxidative stress, protein modifications and oxidative phosphorylation. Int J Biochem Cell Biol 2005;37:927-934.

-46 Grishko VI, Ho R, Wilson GL, Pearsall AW: Diminished mitochondrial DNA integrity and repair capacity in OA chondrocytes. Osteoarthritis and cartilage / OARS, Osteoarthritis Research Society 2009;17:107-113.

47 Guo C-H, Chen P-C: Mitochondrial Free Radicals, Antioxidants, Nutrient Substances, and Chronic Hepatitis C; in (El-Missiry MA, ed) Antioxidant Enzyme. Open Access, InTech, 2012, vol. 10.5772/51315p.^pp. 237 264.

48 Darling EM, Athanasiou KA: Retaining zonal chondrocyte phenotype by means of novel growth environments. Tissue Eng 2005;11:395-403.

49 Frohlich M, Malicev E, Gorensek M, Knezevic M, Kregar Velikonja N: Evaluation of rabbit auricular chondrocyte isolation and growth parameters in cell culture. Cell Biol Int 2007;31:620-625.

50 Takahashi T, Ogasawara T, Asawa Y, Mori Y, Uchinuma E, Takato T, Hoshi K: Three-dimensional microenvironments retain chondrocyte phenotypes during proliferation culture. Tissue Eng 2007;13:15831592.

51 Tait SW, Green DR: Mitochondria and cell death: outer membrane permeabilization and beyond. Nat Rev Mol Cell Biol 2010;11:621-632.

52 Riedl SJ, Salvesen GS: The apoptosome: signalling platform of cell death. Nat Rev Mol Cell Biol 2007;8:405413.

53 Abramson SB, Amin A: Blocking the effects of IL-1 in rheumatoid arthritis protects bone and cartilage. Rheumatology (Oxford) 2002;41:972-980.

54 Caramés B, López-Armada MJ, Cillero-Pastor B, Lires-Dean M, Vaamonde C, Galdo F, Blanco FJ: Differential effects of tumor necrosis factor- $\alpha$ and interleukin- $1 \beta$ on cell death in human articular chondrocytes. Osteoarthritis and Cartilage 2008;16:715-722.

55 Knauper V, Lopez-Otin C, Smith B, Knight G, Murphy G: Biochemical characterization of human collagenase-3. J Biol Chem 1996;271:1544-1550.

56 Selbach M, Schwanhausser B, Thierfelder N, Fang Z, Khanin R, Rajewsky N: Widespread changes in protein synthesis induced by microRNAs. Nature 2008;455:58-63.

57 Wang HQ, Yu XD, Liu ZH, Cheng X, Samartzis D, Jia LT, Wu SX, Huang J, Chen J, Luo ZJ: Deregulated miR155 promotes Fas-mediated apoptosis in human intervertebral disc degeneration by targeting FADD and caspase-3. J Pathol 2011;225:232-242. 